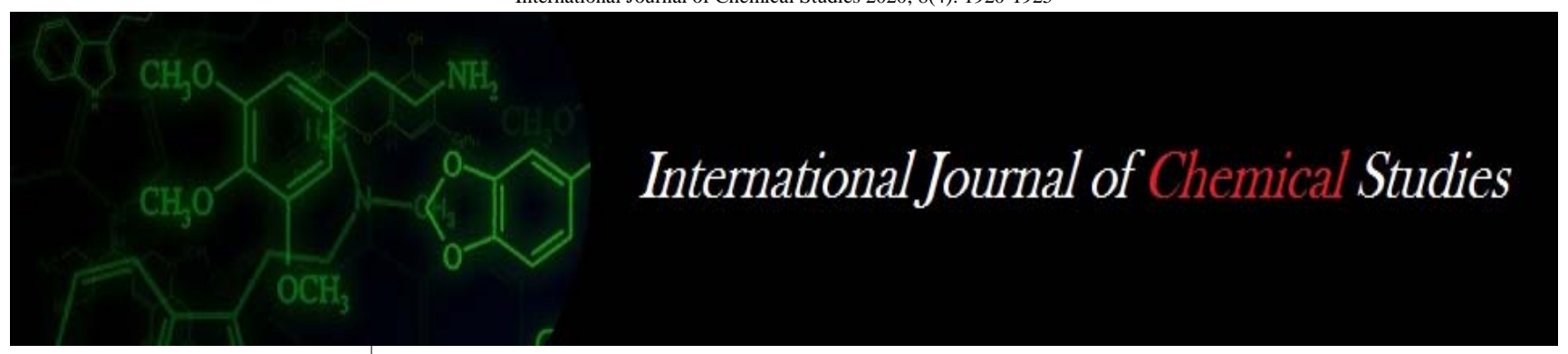

P-ISSN: 2349-8528 E-ISSN: 2321-4902 www.chemijournal.com IJCS 2020; 8(4): 1920-1925 (C) 2020 IJCS

Received: 19-05-2020 Accepted: 21-06-2020

\section{Rajesh Kumar}

Department of Soil Science and Agricultural Chemistry Indira Gandhi Krishi Vishwavidyalaya, Raipur, Chhattisgarh, India

\section{SS Sengar}

Department of Soil Science and Agricultural Chemistry Indira Gandhi Krishi Vishwavidyalaya, Raipur, Chhattisgarh, India

\section{Vivek Patel}

Department of Soil Science and Agricultural Chemistry Indira Gandhi Krishi Vishwavidyalaya, Raipur, Chhattisgarh, India

\section{AK Singh}

Department of Agricultural Statistics $\&$ Social Science

Indira Gandhi Krishi Vishwavidyalaya, Raipur, Chhattisgarh, India

\section{RK Singh}

Department of Agronomy Indira Gandhi Krishi Vishwavidyalaya, Raipur, Chhattisgarh, India

\section{NK Rastogi}

Department of Genetics \& Plant Breeding, Indira Gandhi Krishi Vishwavidyalaya, Raipur, Chhattisgarh, India

\section{PK Chandrakar}

Department of Genetics \& Plant Breeding, Indira Gandhi Krishi Vishwavidyalaya, Raipur, Chhattisgarh, India

Onkar Singh

Department of Soil Science and Agricultural Chemistry Indira Gandhi Krishi Vishwavidyalaya, Raipur, Chhattisgarh, India

\section{Corresponding Author:} Rajesh Kumar Department of Soil Science and Agricultural Chemistry Indira Gandhi Krishi Vishwavidyalaya, Raipur, Chhattisgarh, India

\section{Primary nutrient content and its uptake in finger millet (Eleusine coracana) as influenced by different nutrient management and seed priming}

\author{
Rajesh Kumar, SS Sengar, Vivek Patel, AK Singh, RK Singh, NK Rastogi, \\ PK Chandrakar and Onkar Singh
}

DOI: https://doi.org/10.22271/chemi.2020.v8.i4t.9910

\begin{abstract}
A field experiment was conducted in the experimental plots of DKS farm, IGKV, Bhatapara Dist- Baloda Bazaar, Chhattisgarh during kharif season of the year 2019. The soil of the experimental field was Alfisol and climate was sub-humid with a total rainfall of $872.2 \mathrm{~mm}$ during the crop growth. The objectives of experiment were to the study the effect of various nutrient management and seed priming treatments on $\mathrm{N}, \mathrm{P}$ and $\mathrm{K}$ content and uptake of finger millet. The experiment was laid out in split-plot design. The treatments constituted with five nutrient management N1 (control), N2 (125 kg Neem cake + 1.25 tons ha $^{-1}$ vermicompost), N3 (50“Kg/ha $\mathrm{N}: 50 \mathrm{Kg} / \mathrm{ha} \mathrm{P}_{2} \mathrm{O}_{5}$ : $50 \mathrm{Kg} / \mathrm{ha} \mathrm{K}_{2} \mathrm{O}$ ” and $2 \%$ Borax spray at flowering), N4 (125 Kg Neem cake + 1.25 tons ha ${ }^{-1}$ vermicompost $+50 \mathrm{Kg} / \mathrm{ha} \mathrm{N}: 50 \mathrm{Kg} / \mathrm{ha} \mathrm{P}_{2} \mathrm{O}_{5}: 50 \mathrm{Kg}$ /ha $\mathrm{K}_{2} \mathrm{O}$ and $2 \%$ Borax spray at flowering) and N5 (Recommended dose of fertilizer i.e. $20 \mathrm{Kg} / \mathrm{ha} \mathrm{N}$ ”: 20 $\mathrm{Kg} / \mathrm{ha} \mathrm{P}_{2} \mathrm{O}_{5}: 10 \mathrm{Kg} / \mathrm{ha} \mathrm{K}_{2} \mathrm{O}$ ) in main plots with four priming treatment $\mathrm{P} 1$ (control), P2 (Hydro priming for 6 hrs), P3 (Seed priming with 2\% $\mathrm{KH}_{2} \mathrm{PO}_{4}$ for 6 hrs) and $\mathrm{P} 4$ (Seed priming with 20\% liquid Pseudomonas fluorescens) in sub plots. Results revealed that the nitrogen, phosphorus, and potassium contents in plant tissue were not affected significantly by nutrient management and seed priming treatments. However, the nutrient uptake of nitrogen, phosphorus, and potassium were found in higher range where either higher doses of chemical fertilizers or the chemical fertilizers in combination with organic manures were applied. No significant effect of seed priming was seen for nutrient uptake of these elements by plants.
\end{abstract}

Keywords: Finger millet, primary nutrient, priming

\section{Introduction}

Finger millet (Eleusine coracana L. Gaertn) is an important small millet crop grown in India and has the pride of place in having highest productivity among millets. It is also known as ragi, African millet and bird's foot millet and an important staple food crop in part of eastern and central Africa and India. Grain is higher in protein, fat and minerals than rice, corn or sorghum." Ragi is commonly known as "Nutritious millet" as "the grain is nutritionally superior to many cereals providing proteins, minerals, calcium and vitamins in abundance to the people. When consumed as food, it provides a sustaining diet, especially for people doing hard work. Straw makes valuable fodder for both working and milking animals. Finger millet is considered an especially wholesome food for diabetics." Grain may also be malted and a floor of the malted grain used as cakes or porridge and a nourishing food for infants and invalids. Malnutrition and under nourishment are the major problems of Indian population due to which millets are becoming alternative sources of human food globally as well as in India. Finger millet is an important rainfed crop grown in India. It is commonly known as ragi or madua. In India, it is cultivated in an area of 1.02 million ha with a production of 1.39 million tonne. In Chhattisgarh, it covers an area of 6.30 thousand ha with a production of 1.50 thousand tonne at an average productivity of $238 \mathrm{~kg} \mathrm{ha}^{-1}$ (Anonymous, 2017) ${ }^{[1]}$

The Government of India has declared the year 2018, as "National Year of Millets" and designated "Millets" as "Nutri-Cereals" to recognize the nutritional and socio-economic importance. 


\section{Materials and Methods}

\subsection{Study Site Description}

The field experiment was conducted at DKS farm, IGKV, Bhatapara, Dist- Baloda Bazar, Chhattisgarh during kharif season, 2019. Experimental site was situated at $21^{\circ} 45^{\prime} 25^{\prime \prime}$ North latitude and 81 59'22" East longitudes having an altitude of about $930 \mathrm{~m}$ above Mean sea level (MSL).

\subsection{Experimental details}

The field experiment was conducted in split plot design with three replications. The soil was silty clay loam with neutral $\mathrm{pH}$, non-saline condition, and medium in organic carbon content, low in available nitrogen and sulphur, medium in available phosphorus and high in available potassium, calcium, magnesium and available DTPA extractable micronutrients content. Treatments constituted with five nutrient management N1 (control), N2 (125 kg Neem cake + 1.25 tons ha ${ }^{-1}$ vermicompost), N3 (50 Kg/ha N : $50 \mathrm{Kg} / \mathrm{ha}$ $\mathrm{P}_{2} \mathrm{O}_{5}$ : $50 \mathrm{Kg}$ /ha $\mathrm{K}_{2} \mathrm{O}$ "and $2 \%$ Borax spray at flowering), N4 (125 kg Neem cake +1.25 tons ha ${ }^{-1}$ vermicompost $+50 \mathrm{~kg} / \mathrm{ha}$ $\mathrm{N}$ : $50 \mathrm{Kg} / \mathrm{ha} \mathrm{P}_{2} \mathrm{O}_{5}$ : $50 \mathrm{Kg} / \mathrm{ha} \mathrm{K}_{2} \mathrm{O}$ and $2 \%$ Borax spray at flowering) and $\mathrm{N} 5$ (Recommended dose of fertilizer i.e. 20 $\mathrm{kg} / \mathrm{ha}$ N”: $20 \mathrm{~kg} / \mathrm{ha} \mathrm{P}_{2} \mathrm{O}_{5}$ : $10 \mathrm{~kg} / \mathrm{ha} \mathrm{K}_{2} \mathrm{O}$ ) in main plots with four priming treatment $\mathrm{P} 1$ (control), $\mathrm{P} 2$ (Hydro priming for 6 hrs), P3 (Seed priming with $2 \% \mathrm{KH}_{2} \mathrm{PO}_{4}$ for $6 \mathrm{hrs}$ ) and $\mathrm{P} 4$ (Seed priming with 20\% liquid Pseudomonas fluorescens) in sub plots. Magnesium through MgSO4@20 Kg acre ${ }^{-1}$ and calcium CaO@6 kg acre ${ }^{-1}$ was applied uniformly in all the plots before transplanting except control treatment plots.

\subsection{Cultivation details}

"The experimental plot was dry ploughed twice followed by puddling with tractor mounted cage wheels and later leveled uniformly. Fields were drained and allowed mud to settle for 1 day after the final puddling. Field laid out and prepared bunds for 60 individual plots. Nine lines were demarked manually with the help of mattock for transplanting of finger millet. Water was let into the plots and 21 days old seedlings were transplanted @ one seedling per hill with a spacing of 30 $\mathrm{cm} \times 10 \mathrm{~cm}$. No protective irrigation was given for proper establishment of the seedlings due to occurrence of rainfall following the transplanting operation. Just one irrigation was provided to the crop at $45 \mathrm{DAT}$. The repeated occurrence of rainfall at early and later stages provided sufficient moisture for crop growth reducing the requirement of irrigation. One hand weeding was done at 45 days after transplanting. The weeding was delayed due to continuous rains, which made it difficult to undertake the operation. Fertilizers were applied as per the treatments. Half of nitrogen, full dose of phosphorous and full dose recommended doses of potassium were applied in the form of urea, SSP and MOP as basal dose at the time of transplanting. Another half dose of nitrogen required was applied at maximum tillering stage as urea. Magnesium through MgSO4@20 Kg acre ${ }^{-1}$ and calcium CaO @6 Kg acre $^{-1}$ was applied uniformly in all the plots on $16^{\text {th }}$ july 2019 except for control treatment plots. $2 \%$ Borax spray application was done at the time of flowering. Organic manures in the form of neem cake and vermicompost were applied as per the treatments. Manure was applied uniformly in plots using broadcasting method. The composition of neem cake was $\mathrm{N}$ (Nitrogen 2.61\%), P (Phosphorus 0.78\%), K (Potassium $1.34 \%$ ), and composition of vermicompost was $\mathrm{N}$ (Nitrogen 0.69\%), P (Phosphorus 0.47\%) and K (Potassium 0.71\%). Bifenthrin@1.5 ml/liter was applied to protect plant against stem borer and Hexaconozole @ 1ml/liter was applied to control the blast diseases in finger millet. The crop was harvested manually at 114 DAS. The five representative sample plants were harvested separately, and then crop was harvested from net plot area and kept for threshing. The plants from each plot were sun dried properly to facilitate easy threshing. Threshing was performed manually using the wooden sticks followed by winnowing.

\subsection{Observations recorded}

From each plot, grain and straw yields were recorded for five sample plant and whole plot separately. The straw was sun dried properly in field and the yield was recorded. The grain weight was taken after threshing the crop for each plot, separately. The grain and straw yields were expressed as $\mathrm{kg}$ $\mathrm{ha}^{-1}$. Plant samples were collected at harvest of finger millet and were oven dried with hot air oven until the constant weight was achieved. Dried samples were prepared by grinding grain and straw samples separately with grinding machine and analyzed for plant nutrients content. For nitrogen estimation $0.25 \mathrm{gm}$ of prepared plant samples were taken and transferred to digestion tube. Then $1 \mathrm{gm}$ of salt mixture was added to these plant samples in the digestion tube followed by addition of $5 \mathrm{ml}$ of concentrated sulphuric acid and left for pre digestion overnight. Next morning, the digestion tubes were digested with the help of digester. Total nitrogen was estimated by micro-kjeldhal as per procedure suggested by (AOAC) (1995). For other macronutrient one gram of powdered sample was digested with $10 \mathrm{ml}$ di-acid mixture (nitric acid and perchloric acid at 10:4) after overnight pre digestion. The white residue left at the bottom of flask was diluted with water to known volume after filtration. This extract was used in the estimation of $\mathrm{P}, \mathrm{K}, \mathrm{Ca}, \mathrm{Mg}, \mathrm{S}$ and micronutrients. Phosphorus content of plant samples were measured by vanadomolybdo phosphoric acid yellow color method using an aliquot of diacid digested sample. The intensity of yellow color developed was measured at $430 \mathrm{~nm}$ using spectrophotometer (Jackson, 1973) [5]. Potassium content of plant samples were determined by using the diacid digested extract. The reading of potassium was taken with the help of flame photometer (Chapman and pratt, 1961) ${ }^{[2]}$. The calcium and magnesium in the diacid extract of plant sample was determined by using ammonium chloride-ammonium hydroxide buffer and Eriochrome Black $\mathrm{T}$ indicator by titrating it against versenate solution. Calcium was estimated by titrating the diacid extract of the plant sample against the versenate solution in presence of sodium hydroxide and mureixide (Piper, 1966) ${ }^{[9]}$. Uptake of $\mathrm{N}, \mathrm{P}$ and $\mathrm{K}$ was calculated using the grain and straw yields and nutrient content using the formula.

(\%) nutrient content in plant material $\times$ yield $\left(\mathrm{kgha}^{-1}\right)$ Uptake $\left(\mathrm{kg} \mathrm{ha}^{-1}\right)=$

\section{Results and Discussion \\ 3.1 Effect of different nutrient management and seed priming on $N, P$ and $K$ content of finger millet.}

Nutrient content of finger millet grain followed the order $\mathrm{N}>\mathrm{K}>\mathrm{P}$ where as in finger millet straw, $\mathrm{K}$ content was highest followed by $\mathrm{N}$ and then by $\mathrm{P}$ content (Table 1). The range of variation in primary nutrient content for different treatment combinations was also small. Nitrogen content ranged from $1.18 \%$ to $1.32 \%$ in grain and from $0.44 \%$ to $0.50 \%$ in straw. Phosphorus content in finger millet grain ranged from $0.34 \%$ to $0.39 \%$ and in straw it ranged from $0.16 \%$ to $0.19 \%$. Higher 
content of potassium was found in straw than grain and it ranged from $0.50 \%$ to $0.59 \%$ for grain and $1.21 \%$ to $1.35 \%$ for straw. Higher nutrient content of N (1.32\%), P (0.50\%) and $\mathrm{K}(1.35 \%)$ in grain was associated with N4 treatment. Similarly, higher N (0.50\%), P (0.19\%) and K (1.35\%) content in finger millet straw were associated with $\mathrm{N} 4$ treatment. This might be due to increased nutrient availability of nutrients and higher meristmetic activities of top and roots of the plants. However, it differed non-significantly from other treatments; this might be due to dilution effect, and higher plant available nutrient status of soil. Similar results were also reported by Mondal et al. (2016) ${ }^{[8]}$ and Shruthi et al. $(2018)^{[15]}$.

No trend was found for priming treatments for nutrient content and treatment differed non- significantly due to priming treatments. This might be due to higher rainfall during crop growth. Also, no interaction effect was observed for $\mathrm{N} \times \mathrm{P}$. similar results were reported by Zida et al. (2017) ${ }^{[16]}$ and Damalas et al. (2019) ${ }^{[3]}$.

Table 1: Effect of "integrated nutrient management” and seed priming on N, P and K content (\%) of finger millet

\begin{tabular}{|c|c|c|c|c|c|c|}
\hline \multirow{2}{*}{$\begin{array}{c}\text { Treatment } \\
\text { Nutrient management }\end{array}$} & \multicolumn{2}{|c|}{$\begin{array}{l}\text { Nitrogen content } \\
(\%)\end{array}$} & \multicolumn{2}{|c|}{$\begin{array}{l}\text { Phosphorus content } \\
(\%)\end{array}$} & \multicolumn{2}{|c|}{$\begin{array}{l}\text { Potassium content } \\
(\%)\end{array}$} \\
\hline & Grain & Straw & Grain & Straw & Grain & Straw \\
\hline N1: Control & 1.18 & 0.44 & 0.38 & 0.16 & 0.50 & 1.21 \\
\hline N2:125 kg Neem cake +1.25 tons $\mathrm{ha}^{-1}$ vermicompost & 1.23 & 0.47 & 0.34 & 0.17 & 0.52 & 1.24 \\
\hline $\begin{array}{c}\text { N3: “50 kg/ha N: } 50 \mathrm{~kg} / \mathrm{ha} \mathrm{P}_{2} \mathrm{O}_{5}: 50 \mathrm{~kg} / \mathrm{ha} \mathrm{K}_{2} \mathrm{O} \text { and”2\% Borax spray at } \\
\text { flowering”. }\end{array}$ & 1.25 & 0.46 & 0.39 & 0.19 & 0.54 & 1.29 \\
\hline N4: N2+N3 & 1.32 & 0.50 & 0.39 & 0.19 & 0.59 & 1.35 \\
\hline $\begin{array}{l}\text { N5: "Recommended dose of fertilizer i.e. } 20 \mathrm{~kg} / \mathrm{ha} \mathrm{N}: 20 \mathrm{~kg} / \mathrm{ha} \mathrm{P}_{2} \mathrm{O}_{5}: 10 \mathrm{~kg} \\
\qquad / \text { ha } \mathrm{K}_{2} \mathrm{O} \text { ” }\end{array}$ & 1.25 & 0.48 & 0.36 & 0.18 & 0.54 & 1.28 \\
\hline SEm \pm & 0.03 & 0.02 & 0.01 & 0.01 & 0.02 & 0.04 \\
\hline C.D. $(\mathrm{P}=0.05)$ & NS & NS & NS & NS & NS & NS \\
\hline \multicolumn{7}{|l|}{ Priming } \\
\hline P1: Control & 1.20 & 0.46 & 0.39 & 0.18 & 0.53 & 1.30 \\
\hline P2:Hydro priming for 6hrs & 1.26 & 0.48 & 0.38 & 0.18 & 0.53 & 1.27 \\
\hline P3:Seed priming with $2 \% \mathrm{KH}_{2} \mathrm{PO}_{4}$ for 6 hrs & 1.26 & 0.46 & 0.36 & 0.18 & 0.53 & 1.27 \\
\hline P4: Seed priming with $20 \%$ liquid Pseudomonas fluorescens. & 1.25 & 0.47 & 0.37 & 0.18 & 0.55 & 1.25 \\
\hline SEm \pm & 0.02 & 0.02 & 0.01 & 0.01 & 0.01 & 0.03 \\
\hline C.D. $(\mathrm{P}=0.05)$ & NS & NS & NS & NS & NS & NS \\
\hline Interaction & NS & NS & NS & NS & NS & NS \\
\hline
\end{tabular}

3.2 Effect of integrated nutrient management and seed priming on $\mathbf{N}, \mathbf{P}$ and $\mathrm{K}$ uptake of finger millet.

3.2.1“Effect of integrated nutrient management and seed priming on Nitrogen uptake (kg/ha).

Nitrogen uptake of finger millet grains varied from 20.35 $\mathrm{kg} / \mathrm{ha}$ to $38.54 \mathrm{~kg} / \mathrm{ha}$ (Table 2). The highest $\mathrm{N}$ uptake in finger millet grains was found in N4 treatment $(38.54 \mathrm{~kg} / \mathrm{ha})$ which was significantly higher than other treatments and the lowest $\mathrm{N}$ uptake was found in N1 treatment (20.35 kg/ha). In case of finger millet straw, $\mathrm{N}$ uptake varied from $10.57 \mathrm{~kg} / \mathrm{ha}$ to 20.41 $\mathrm{kg} / \mathrm{ha}$. The highest $\mathrm{N}$ uptake in finger millet straw was found in N4 treatment (20.41 kg/ha) which was significantly higher than the other treatments. The lowest $\mathrm{N}$ uptake in straw was found in $\mathrm{N} 1$ treatment $(10.57 \mathrm{~kg} / \mathrm{ha})$. Total $\mathrm{N}$ uptake of finger millet varied from $30.92 \mathrm{~kg} / \mathrm{ha}$ to $58.95 \mathrm{~kg} / \mathrm{ha}$. Trend remains same for total $\mathrm{N}$ uptake and the highest $\mathrm{N}$ uptake was found in N4 (58.95 kg/ha), which was significantly higher than the all other treatments. The lowest total $\mathrm{N}$ uptake was found in N1 treatment (30.92 kg/ha).

Nitrogen uptake of finger millet grains and straw and total $\mathrm{N}$ uptake differed non-significantly between priming treatments. The highest $\mathrm{N}$ uptake of finger millet grains was found in P3 (30.69 kg/ha) and the lowest $\mathrm{N}$ uptake in finger millet grains was recorded in P1 treatment (28.82 kg/ha). In case of finger millet straw, "the highest $\mathrm{N}$ uptake was found in P4 $(15.87 \mathrm{~kg} / \mathrm{ha})$ and the lowest $\mathrm{N}$ uptake was recorded in P3 treatment (14.86 kg/ha).The highest total $\mathrm{N}$ uptake was found in $\mathrm{P} 4$ treatment $(46.31 \mathrm{~kg} / \mathrm{ha})$ and the lowest total $\mathrm{N}$ uptake was recorded in P1 treatment (43.71 kg/ha).The interaction effect of $\mathrm{N} \times \mathrm{P}$ for $\mathrm{N}$ uptake of finger millet grain, straw and for total $\mathrm{N}$ uptake was found to be differed non-significantly.” The increase uptake of nitrogen in plots where higher doses of fertilizer along with organic manure was used might be due to increased dry matter production and due to balanced release of these nutrients into soil upon manure decomposition, which resulted in vigorous growth and uptake of nutrients. Similar results were reported by Divyashree et al. (2018) and Roy et al. (2018).

\subsection{2“Effect of integrated nutrient management and seed} priming on Phosphorus uptake (kg/ha).

Phosphorus uptake of finger millet grains varied from 6.53 $\mathrm{kg} / \mathrm{ha}$ to $11.52 \mathrm{~kg} / \mathrm{ha}$ (Table 2). Highest $\mathrm{P}$ uptake by finger millet grain was found in $\mathrm{N} 4(11.52 \mathrm{~kg} / \mathrm{ha})$ which was significantly higher than the other treatments. The lowest $\mathrm{P}$ uptake was found in $\mathrm{N} 1$ treatment $(6.53 \mathrm{~kg} / \mathrm{ha})$. In case of straw, P uptake of fingermillet straw varied from $3.97 \mathrm{~kg} / \mathrm{ha}$ to $7.86 \mathrm{~kg} / \mathrm{ha}$. The highest $\mathrm{P}$ uptake was found in $\mathrm{N} 4$ treatment $(7.86 \mathrm{~kg} / \mathrm{ha})$ which was significantly higher than the other treatments. The lowest $\mathrm{P}$ uptake was found in N1 treatment $(6.53 \mathrm{~kg} / \mathrm{ha})$.Total $\mathrm{P}$ uptake of finger millet varied from $10.50 \mathrm{~kg} / \mathrm{ha}$ to $19.38 \mathrm{~kg} / \mathrm{ha}$. The highest total P uptake was found in N4 treatment (19.38 kg/ha) which was significantly higher over all other treatments and the lowest $\mathrm{P}$ uptake was found in N1 treatment (10.50 kg/ha).

Phosphorus uptake in finger millet grains and straw and total $\mathrm{P}$ uptake differed non-significantly between priming treatments. "The highest P uptake in grains was found in P1 treatment $(9.36 \mathrm{~kg} / \mathrm{ha})$ and the lowest $\mathrm{P}$ uptake was recorded in P3 treatment $(8.61 \mathrm{~kg} / \mathrm{ha})$. In case of straw, the highest P uptake was found in $\mathrm{P} 4$ treatment $(6.19 \mathrm{~kg} / \mathrm{ha})$ and the lowest $\mathrm{P}$ uptake was recorded in P3 treatment $(5.74 \mathrm{~kg} / \mathrm{ha})$.Total uptake of P by crop was found highest in P3 treatment (15.25 $\mathrm{kg} / \mathrm{ha}$ ) and the lowest $\mathrm{P}$ uptake was recorded in P2 treatment (14.35 kg/ha). No interaction effect of $\mathrm{N} \times \mathrm{P}$ for $\mathrm{P}$ uptake of grains, straw and total $\mathrm{P}$ uptake was found significant.” 
"The increased uptake of phosphorus by finger millet in plots where higher doses of fertilizer along with organic manure was used might be due to solubilizing effect of organic acids which are produced from the decomposition of organic matter and reducing the fixation of phosphorus and increasing the availability of phosphorus resulting in higher dry matter mass production and uptake of phosphorus by fingermillet. Similar results were reported by Khan et al. (2011) and Prabudoss et al. (2014).

\subsubsection{Effect of integrated nutrient management and seed priming on Potassium uptake (kg/ha).}

"Potassium uptake of finger millet grains varied from 8.67 $\mathrm{kg} /$ ha to $17.10 \mathrm{~kg} / \mathrm{ha}$ (Table 2). The highest K uptake of finger millet grains was found in N4 treatment $(17.10 \mathrm{~kg} / \mathrm{ha})$ which was significantly higher than all other treatments. The lowest $\mathrm{K}$ uptake was found in $\mathrm{N} 1$ treatment $(8.67 \mathrm{~kg} / \mathrm{ha})$. In case of $\mathrm{K}$ uptake of finger millet straw, variation was recorded from $29.54 \mathrm{~kg} / \mathrm{ha}$ to $54.95 \mathrm{~kg} / \mathrm{ha}$. The highest $\mathrm{K}$ uptake by finger millet in straw was found in N4 treatment $(54.95 \mathrm{~kg} / \mathrm{ha})$ which was statistically superior to all other treatments. The lowest $\mathrm{K}$ uptake by finger millet straw was found in $\mathrm{N} 1$ (29.54 kg/ha). Total K uptake of finger millet crop varied from $38.21 \mathrm{~kg} / \mathrm{ha}$ to $72.05 \mathrm{~kg} / \mathrm{ha}$. The highest total K uptake was found in N4 treatment $(72.05 \mathrm{~kg} / \mathrm{ha})$ which was significantly higher than all other treatments. The lowest total $\mathrm{N}$ uptake was found in N1 treatment (38.21 kg/ha).

Potassium uptake of finger millet in grains, straw and total $\mathrm{K}$ uptake differed non-significantly between priming treatments. The highest $\mathrm{K}$ uptake by finger millet grain was found in P4 treatment (13.48 kg/ha)and the lowest $\mathrm{K}$ uptake was recorded in $\mathrm{P} 1$ treatment $(12.68 \mathrm{~kg} / \mathrm{ha})$.In case of straw, the highest $\mathrm{K}$ uptake was found in P4 treatment $(42.13 \mathrm{~kg} / \mathrm{ha})$ and the lowest $\mathrm{K}$ uptake was recorded in P3 (41.14 kg/ha).Total K uptake by fingermillet crop was highest in P4 (55.61 kg/ha)and the lowest $\mathrm{K}$ uptake was recorded in P3 (53.86 kg/ha). The interaction effect of $\mathrm{N} \times \mathrm{P}$ for $\mathrm{K}$ uptake by finger millet grain, straw and total $\mathrm{K}$ uptake was found to be differed nonsignificantly.

The highest potassium uptake might be because potassium is likely to be maintained in exchangeable form in soils treated with organic manures due to high exchange capacity of organic colloids formed during decomposition of organic manure which in turn restricted the $\mathrm{K}^{+}$ions getting fixed by inorganic clay particles in soil which results in increased in growth parameters and higher $\mathrm{K}$ uptake by finger millet. Similar results were reported by Mondal et al. (2016) ${ }^{[8]}$ and Roy et al. (2018) ${ }^{[14]}$.

Table 2: Effect of integrated nutrient management and seed priming on N, P and K uptake of finger millet

\begin{tabular}{|c|c|c|c|c|c|c|c|c|c|}
\hline \multirow{2}{*}{$\begin{array}{c}\text { Treatment } \\
\text { Nutrient management }\end{array}$} & \multicolumn{3}{|c|}{$\begin{array}{c}\text { Nitrogen Uptake } \\
\text { (kg/ha) }\end{array}$} & \multicolumn{3}{|c|}{$\begin{array}{c}\text { Phosphorus Uptake } \\
\text { (kg/ha) }\end{array}$} & \multicolumn{3}{|c|}{$\begin{array}{c}\text { Potassium Uptake } \\
\text { (kg/ha) }\end{array}$} \\
\hline & Grain & Straw & total & Grain & Straw & total & Grain & Straw & Total \\
\hline N1: Control & $20.35^{\mathrm{d}}$ & $10.57^{\mathrm{e}}$ & $30.92^{\mathrm{e}}$ & $6.53^{\mathrm{d}}$ & $3.97^{\mathrm{d}}$ & $10.50^{\mathrm{e}}$ & $8.67^{\mathrm{d}}$ & $29.54^{\mathrm{d}}$ & $38.21^{\mathrm{d}}$ \\
\hline N2:125 kg Neem cake +1.25 tons ha ${ }^{-1}$ vermicompost & $28.42^{\mathrm{C}}$ & $13.84^{\text {cd }}$ & $42.26^{\mathrm{d}}$ & $7.92^{\mathrm{c}}$ & $5.04^{\mathrm{c}}$ & $12.97^{\mathrm{d}}$ & $11.91^{\mathrm{c}}$ & $36.65^{\mathrm{c}}$ & $48.56^{\mathrm{c}}$ \\
\hline N3: “50kg/ha N: $50 \mathrm{~kg} / \mathrm{ha} \mathrm{P}_{2} \mathrm{O}_{5}: 50 \mathrm{~kg} / \mathrm{ha} \mathrm{K}_{2} \mathrm{O}$ and2\% Borax spray at flowering”. & $32.93^{\mathrm{b}}$ & $16.34^{\mathrm{b}}$ & $49.27^{\mathrm{b}}$ & $10.35^{\mathrm{b}}$ & $6.77^{\mathrm{b}}$ & $17.12^{\mathrm{b}}$ & $14.17^{\mathrm{b}}$ & $45.72^{\mathrm{b}}$ & $59.89^{\mathrm{b}}$ \\
\hline N4: N2+N3 & $38.54^{\mathrm{a}}$ & $20.41^{\mathrm{a}}$ & $58.95^{\mathrm{a}}$ & $11.52^{\mathrm{a}}$ & $7.86^{\mathrm{a}}$ & $19.38^{\mathrm{a}}$ & $17.10^{\mathrm{a}}$ & $54.95^{\mathrm{a}}$ & $72.05^{\mathrm{a}}$ \\
\hline N5: "Recommended dose of fertilizer i.e. $20 \mathrm{~kg} / \mathrm{ha} \mathrm{N} \mathrm{:} 20 \mathrm{~kg} / \mathrm{ha} \mathrm{P}_{2} \mathrm{O}_{5}: 10 \mathrm{~kg} / \mathrm{ha} \mathrm{K} \mathrm{O}_{2}$ ” & $30.19^{c}$ & $15.62^{\mathrm{bc}}$ & $45.81^{\mathrm{c}}$ & $8.82^{\mathrm{c}}$ & $5.94^{\mathrm{bc}}$ & $14.76^{\mathrm{c}}$ & $12.97^{\mathrm{bc}}$ & $41.29^{\mathrm{bc}}$ & $54.26^{\mathrm{bc}}$ \\
\hline SEm \pm & 0.72 & 0.64 & 0.75 & 0.26 & 0.32 & 0.30 & 0.54 & 1.66 & 1.94 \\
\hline C.D. $(\mathrm{P}=0.05)$ & 2.36 & 2.09 & 2.45 & 0.83 & 1.03 & 0.99 & 1.77 & 5.40 & 6.33 \\
\hline \multicolumn{10}{|l|}{ Priming } \\
\hline P1: Control & 28.82 & 14.89 & 43.71 & 9.36 & 5.89 & 15.25 & 12.68 & 42.06 & 54.74 \\
\hline P2:Hydro priming for $6 \mathrm{hrs}$ & 30.40 & 15.81 & 46.21 & 9.14 & 5.84 & 14.98 & 12.98 & 41.20 & 54.17 \\
\hline P3:Seed priming with $2 \% \mathrm{KH}_{2} \mathrm{PO}_{4}$ for $6 \mathrm{hrs}$ & 30.69 & 14.86 & 45.55 & 8.61 & 5.74 & 14.35 & 12.72 & 41.14 & 53.86 \\
\hline P4:Seed priming with $20 \%$ liquid Pseudomonas fluorescens. & 30.44 & 15.87 & 46.31 & 9.01 & 6.19 & 15.20 & 13.48 & 42.13 & 55.61 \\
\hline SEm \pm & 0.54 & 0.72 & 1.10 & 0.35 & 0.23 & 0.40 & 0.29 & 1.36 & 1.35 \\
\hline C.D. $(\mathrm{P}=0.05)$ & NS & NS & NS & NS & NS & NS & NS & NS & NS \\
\hline Interaction & NS & NS & NS & NS & NS & NS & NS & NS & NS \\
\hline
\end{tabular}

Means of a particular parameter in columns for nutrient management and seed priming followed by same letter(s) are statistically non-significant at $\mathrm{P}=0.05$.

\subsection{Effect of integrated nutrient management and seed priming on yield of finger millet \\ 3.3.1 Grain yield}

Grain "yield of finger millet varied from 17.3 q/ha to 29.2 $\mathrm{q} /$ ha (Table 3). The highest grain yield was recorded in N4 treatment $(29.2 \mathrm{q} / \mathrm{ha})$ which was at par with N3 treatment (26.4 q/ha) and significantly higher than the other treatments. The lowest grain yield was recorded in N1 treatment (17.2q/ha). Grain yield differed non-significantly between priming treatments. The highest grain yield was found in P3 and P4 treatment $(24.1 \mathrm{q} / \mathrm{ha})$ and the lowest yield was recorded in P2 treatment (23.9 q/ha). The interaction effect of $\mathrm{N} \times \mathrm{P}$ for grain yield was found to be differed non-significantly. Maximum grain yield was recorded in N3P4 (26.6 q/ha) and the minimum grain yield was recorded in N1P1 treatment combinations" (17.2 q/ha). Higher grain yield with combined application of organic manure and inorganic fertilizers may be due to increased availability of nutrients which improved the soil properties, this in turn, increased absorption and translocation of nutrients by crop leading to increased production of photosynthates by the crop. Organic manures provided favorable environment for microorganisms like Azospirillium which fixes atmospheric nitrogen available to plant and PSB which converts insoluble phosphate into soluble forms by secreting organic acids. These results are in line with the findings of Malinda et al. (2015) ${ }^{[7]}$ and Rao et al. (2018) ${ }^{[14]}$.

\subsubsection{Straw yield}

Straw yield of finger millet varied from 24.5 q/ha to 40.9 q/ha (Table 3). The highest straw yield was recorded in N4 treatment (40.9q/ha) which was significantly higher than the other treatments. The lowest straw yield was found in N1 treatment (24.5 q/ha). Straw yield differed non-significantly between priming treatments. The highest straw yield was found in P4treatment (33.8q/ha) followed by P3 (32.2 q/ha) and the lowest straw yield was recorded in P1treatment (31.9 $\mathrm{q} / \mathrm{ha}$ ). The interaction effect of $\mathrm{N} \times \mathrm{P}$ for straw yield was found to be differed non-significantly. Maximum straw yield was recorded in N4P3 (40.8 q/ha) and the lowest straw yield was recorded in N1P1treatment combinations (26.6 q/ha). Higher straw yield recorded in integrated nutrient management plots 
may be due to enhancement of the photosynthetic rate resulting in more vegetative growth and dry matter production. These results are in conformity with the findings of Malinda et al. (2015) ${ }^{[7]}$.

\subsubsection{Biological yield}

Biological yield of finger millet varied from $41.8 \mathrm{q} / \mathrm{ha}$ to 70.1 $\mathrm{q} /$ ha (Table 3). The highest biological yield was found in N4 treatment $(70.1 \mathrm{q} / \mathrm{ha})$ which was significantly higher than the other treatments. The lowest biological yield was found in N1treatment (41.8 q/ha). Biological yield differed nonsignificantly between priming treatments. "The highest Biological yield was found in P4 treatment $(58.0 \mathrm{q} / \mathrm{ha})$ followed by P3 (56.3 q/ha) and the lowest biological yield was recorded in P1 treatment (55.8 q/ha). The interaction effect of $\mathrm{N} \times \mathrm{P}$ for biological yield was found to be differed non-significantly. Maximum biological yield was recorded in N4P3 (40.8 q/ha) and the lowest biological yield was recorded in N1P1 treatment combinations (22.6 q/ha)."Greater total yield of finger millet in integrated nutrient management is due to enhanced growth and yield parameters. The results obtained were in close conformity of Rani et al. (2017) ${ }^{\text {[11] }}$. Seed priming with 20\% Pseudomonas fluorescens and $2 \%$ $\mathrm{KH}_{2} \mathrm{PO}_{4}$ showed higher yield than hydro priming and control however their effects were masked by the rainfall on the week of sowing and next week after showing. Similar results were obtained by Zida et al. (2017) ${ }^{[16]}$.

Table 3: Effect of integrated nutrient management and seed priming on grain, straw and biological yield of finger millet

\begin{tabular}{|c|c|c|c|}
\hline Treatment & $\begin{array}{c}\text { Grain yield } \\
\text { (q/ha) }\end{array}$ & \begin{tabular}{|c|} 
Straw yield \\
$(\mathrm{q} / \mathrm{ha})$
\end{tabular} & $\begin{array}{c}\text { Biological yield } \\
\text { (q/ha) }\end{array}$ \\
\hline \multicolumn{4}{|l|}{ Nutrient management } \\
\hline N1: Control & $17.3^{\mathrm{e}}$ & $24.5^{\mathrm{e}}$ & $41.8^{\mathrm{e}}$ \\
\hline N2:125 kg Neem cake +1.25 tons ha $^{-1}$ vermicompost & $23.0^{\mathrm{d}}$ & $29.5^{\mathrm{d}}$ & $52.6^{\mathrm{d}}$ \\
\hline N3: $50 \mathrm{~kg} / \mathrm{ha} \mathrm{N}: 50 \mathrm{~kg} / \mathrm{ha} \mathrm{P}_{2} \mathrm{O}_{5}: 50 \mathrm{~kg} / \mathrm{ha} \mathrm{K}_{2} \mathrm{O}$ and $2 \%$ Borax spray at flowering. & $26.4^{\mathrm{b}}$ & $35.5^{\mathrm{b}}$ & $61.9^{\mathrm{b}}$ \\
\hline N4: N2+N3 & $29.2^{\mathrm{a}}$ & $40.9^{\mathrm{a}}$ & $70.1^{\mathrm{a}}$ \\
\hline N5: Recommended dose of fertilizer i.e. $20 \mathrm{~kg} / \mathrm{ha} \mathrm{N}: 20 \mathrm{~kg} / \mathrm{ha} \mathrm{P}_{2} \mathrm{O}_{5}: 10 \mathrm{~kg} / \mathrm{ha} \mathrm{K}_{2} \mathrm{O}$ & $24.3^{\mathrm{c}}$ & $32.2^{\mathrm{c}}$ & $56.5^{\mathrm{c}}$ \\
\hline SEm \pm & 0.09 & 0.80 & 0.86 \\
\hline C.D. $(\mathrm{P}=0.05)$ & 0.29 & 2.60 & 2.64 \\
\hline \multicolumn{4}{|l|}{ Priming } \\
\hline P1: Control & 23.9 & 31.9 & 55.8 \\
\hline P2:Hydro priming for 6hrs & 24.0 & 32.1 & 56.1 \\
\hline P3:Seed priming with $2 \% \mathrm{KH}_{2} \mathrm{PO}_{4}$ for $6 \mathrm{hrs}$ & 24.1 & 32.2 & 56.3 \\
\hline P4: Seed priming with $20 \%$ liquid Pseudomonas fluorescens. & 24.1 & 33.8 & 58.0 \\
\hline SEm \pm & 0.11 & 0.79 & 0.7 \\
\hline C.D. $(P=0.05)$ & NS & NS & NS \\
\hline Interaction & NS & NS & NS \\
\hline
\end{tabular}

Means of a particular parameter in columns for nutrient management and seed priming followed by same letter(s) are statistically non-significant at $\mathrm{P}=0.05$

\section{Conclusion}

Nutrient content of all the secondary nutrients in plant tissue differed non-significantly due to any of the applied treatment and varied from $0.46 \%$ to $0.51 \%, 0.26 \%$ to $0.29 \%$ and $0.14 \%$ to $16 \%$ for calcium, magnesium and sulphur respectively in finger millet grain where as in straw it ranged from $0.65 \%$ to $0.68 \%, 0.43 \%$ to $0.49 \%$ and $0.25 \%$ to $0.30 \%$ for calcium, magnesium and sulphur, respectively. The nutrient uptake of primary nutrient found significantly high due to enhanced growth and yield parameters in integrated nutrient management. Higher uptake of nitrogen $(38.54 \mathrm{~kg} / \mathrm{ha})$, phosphors (11.52 kg/ha) and potassium (17.10 kg/ha) was found in N4 treatment in finger millet grain, similarly higher uptake of nitrogen (20.41 kg/ha), phosphors (7.86 kg/ha) and potassium (54.95kg/ha) was found in finger millet straw in N4 treatment only.

\section{Acknowledgement}

The authors feel privileged to thank to Dr. S.S. Sengar (Dean, college of agriculture and research station, Chhuikhadan, Rajnandgaon (C. G.) for his continuous help, support and guidance throughout this research work.

\section{Reference}

1. Anderson KA. Moller, G. Alternative Catalyst to Mercury for Kjeldahl Determination of Nitrogen in Water and Wastewater Samples. J. AOAC Int. 1995; 78 (6), 1516-1519.
2. Anonymous. Ministry of agriculture and farmers welfare, Govt. of India. (ON1704), 2017.

3. Chapman HD, Pratt PF. Methods of analysis for soils. Plants and Waters, 1961, 169-176.

4. Damalas, Christos, Koutroubas D, Fotiadis. HydroPriming Effects on Seed Germination and Field Performance of Faba Bean in Spring Sowing. Agriculture. 2019; 9:201.

5. Divyashree, U. Dinesh Kumar, M. and Ganapathi, Effect of different fertilizer levels on nutrient uptake and yield of little millet (Panicum sumatrense). International Journal of Science and Nature, 2018; 9(2), 201-205.

6. Khan MA, Rajamani K, Reddy A. Nutrient content, Uptake, Soil Enzymatic Activity and Available Nutrient status of Sweet sorghum as influenced by Nutrient Management in Agrisilvi culture system. Indian Journal of Dryland Agricultural Research and Development. 2011; 26(1):83-89.

7. Malinda S, Thilakarathna, Raizada MN. A Review of Nutrient Management Studies Involving Finger Millet in the Semi-Arid Tropics of Asia and. Africa PeerReviewed Multi-Disciplinary International Journal, 2015, 19.

8. Mondal S, Mallikarjun M, Ghosh M, Ghosh DC, Timsina J. Influence of integrated nutrient management (INM) on nutrient use efficiency, soil fertility and productivity of hybrid rice. Archives of Agronomy and Soil Science. 2016; 62(11):1521-1529. 
9. Piper CS. Soil and plant analysis., (Hans Publishers: Bombay. India), 1966.

10. Prabudoss V, Jawahar S, Shanmugaraja P, Dhanam K. Effect of integrated nutrient management on growth, yieldand economics of transplanted kodo millet. European Journal of Biotechnology and Bioscience. 2018; 1(4):30-33

11. Rani YS, Triveni U, Patro TSSK. Integrated Nutrient Management for Enhancing the Soil Health, Yield and Quality of Little Millet (Panicumsumatrense). International Journal of Bio-resource and Stress Management. 2017; 8(1):26-32.

12. Rao N, Swamy M. Soil Microbial Count and Dehydrogenase Activity of Direct Seeded Rice as Influenced by Integrated Nutrient Management. Int. J Curr. Microbiol. App. Sci. 2019; 8(2):1345-1350.

13. Raundal PU, Pawar PP, Musamade AM, Mahajan MS, Desale SB. Response of little millet varieties to different levels of fertilizers under rainfed condition. A peerReviewed Multi-Disciplinary International Journal, 2017, 18.

14. Roy AK, Ali N, Lakra RK, Alam P, Mahapatra P, Narayan R. Effect of integrated nutrient management practices on nutrient uptake, yield of finger millet (Eleusine coracana L. Gaertn.) and post-harvest nutrient availability under rainfed condition of Jharkhand. International Journal of Current Microbiology and Applied Sciences, 2018; 7(8):339-347.

15. Shruthi, Gowdpa, DARC, Basavaraja PK. Nutrient Content and Uptake in Finger Millet as Influenced by Fym and Biofertilizers along with Different Levels of Phosphorus and Potassium. International Journal of Agriculture Sciences, 2018, 6817-6819.

16. Zida PE, Néya BJ, Soalla WR, Sereme P, Lund OS. Hydro priming of pearl millet (Pennisetum glaucum L.) in Northern and Central Burkina Faso applying six hours of soaking and overnight drying of seeds, 2017. 